\title{
The Influence of Organizational Culture and Teachers' Performance on the Students' Learning Achievement
}

\author{
Dian Sumantri ${ }^{1 *}$, Bukman Lian², Mulyadi ${ }^{2}$
}

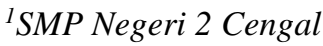 \\ ${ }^{2}$ Universitas PGRI Palembang \\ *Corresponding Author. Email: dian.sumantri17@gmail.com
}

\begin{abstract}
This study aims to determine the effect of organizational culture and teacher performance on student achievement of grade VIII at Junior Public High School (SMPN) 2 of Cengal district. This research uses descriptive quantitative method. The population of the study was 189 students, and the number of sample was 66 students. The sampling technique in this study was Simple Random Sampling. The data collection technique is by using questionnaires, documentation and literature review. The data were analyzed partially and simultaneously. The results of this study indicate that: (1) organizational culture has a significant effect on the student learning achievement of grade VIII at SMPN 2 Cengal; (2) teacher performance has a significant effect on the student learning achievement of grade VIII at SMPN 2 Cengal; and (3) Both organizational culture and teacher performance have a significant effect on the student learning achievement of grade VIII at SMPN 2 Cengal.
\end{abstract}

Keywords: Organizational Culture, Teachers’ Performance, Learning Achievement

\section{INTRODUCTION}

Science has developed rapidly and cannot be separated from educational institutions that organize learning activities. By promoting exploration of the students' skills actively and creatively in carrying out learning, Law Number 20 of 2003 provides an explanation about students in article 1 paragraph (4). It is stated that students are members of society who make an effort to develop their potential through the learning process available at certain paths, levels, and types of education [1].

A student has the right to get the proper education as a member of community. One of the ways to get this education is by attending formal education which has a goal to be achieved. National education is carried out with the aim of developing the potential contained in students so that they become human beings who are religious, virtuous, healthy, knowledgeable, capable, creative, independent, democratic, and responsible [2]

The student who has taken formal education should follow every aspect organized by the institution. Learning carried out in formal education has terms and conditions that must be met, both administratively and technically. One of the things required is that there is a measurement of the success of the implementation of learning in the classroom. The intended success is the achievement obtained by students after being actively involved in the learning process in the classroom, as evidenced by understanding the concepts or material being taught. The proof of this understanding can be done through tests or exams to determine student learning outcomes.

According to Sudjana [3], student learning achievement is a change in behavior as a result of learning activities. In a broader sense, it covers the cognitive, affective, and psychomotor fieldsAlthough the life success of students is not entirely determined by their learning outcomes, it becomes important to have the ability or competence to compete in the global world.

It was stated earlier that there are significant internal factors in the students to achieve good learning outcomes, such as physical and psychological factors. However, the external factors also have a big impact on the achievement of learning outcomes. As the environment is able to influence a person's character, so are the learning outcomes. The external factors are parents, the community, schools, and teachers who organize learning [4]

The above description confirms that there are many factors that need to be considered so that the achievement of student learning outcomes can be optimal. More importantly, the closest factors are family, school culture, and learning organized by the 
teacher. This study is focused on these external factors, especially on the aspects of school culture or known as organizational culture and the implementation of learning by teachers that can be measured through teacher performance.

These things have a clear connection as the function of the implementation of education including to develop abilities and to shape the character and civilization of the nation with dignity in the context of the nation's life (Ministry of National Education) For this reason, the school culture which is known for its high academic nuances needs to be maintained. It is hoped to reach the goals and functions of education nationally in the context of generation building.

The school culture or organizational culture is a shared system of meaning (perception) by organizational members that distinguishes among the organizations [5]. It is believed that the organizational culture held by schools is able to build the character which is in relation to the learning outcomes obtained by students. If the school has a highly disciplined organizational culture, it will gradually influence students to be disciplined. Likewise, if the culture held by a school does not emphasize the affective aspect, yet on the cognitive aspects only, then discipline becomes less important. The success is determined only on the scientific aspects of the students.

Moreover, it is clear that a school that has a good organizational culture will form a good personality and the learning outcomes will be better. One component that can also be a reference whether or not a good culture applied in schools as an organizational unit is the implementation of learning by teachers in the classroom. If the organizational culture goes well, it is believed that teachers will carry out learning well to achieve both instructional and national education goals.

To measure whether or not the implementation of learning in class organized by the teacher can be determined by measuring the performance of the teacher. It is clear that the teacher performance is intended specifically for the aspects of implementing learning in the classroom. According to Rubiyanto [6] the teacher performance in the learning process is based on three indicators, namely mastery of teaching materials, the ability to manage learning and the commitment to carry out tasks. It is clear that each component is able to contribute in optimizing or increasing the student learning achievement.

The related topic has been studied by Khairani [7] The results of her research suggested that the culture of school organization had an effect on the student achievement. The indicators are the harmonious environment in the school community, the hopes and optimism of the school community, the cleanliness, and the beauty of school environment. In short, teacher performance affects student achievement.

The problems related to organizational culture also arise in the Public Junior High School (SMPN) 2 Cengal. Based on the preliminary observation, the perception of the school member towards organizational culture is not one view. Likewise, the results of the measurement of the overall teacher performance carried out by the principal showed the variation. Judging from the formal legal records from the aspect of student learning achievement, it is sufficient by the minimum criteria, but basically these results are processed by the teacher, in fact there are still students who have not completed the subject matter based on the teacher's narrative.

Regarding the phenomena that have occurred from the description above, such matters should be studied intensively. In order to focus more on the cases, the research is entitled "The influence of organizational culture and teacher performance on student achievement

\section{METHODS}

The location that becomes the object of this research is SMPN 2 Cengal, which is located on Jalan Raya Cengal Village, Cengal District, Ogan Komering Ilir Regency, South Sumatra Province. The schedule for the implementation of this research started from July to September 2020. According to Sugiyono [8] the research method is a scientific way to get the data with specific purposes and uses The research method is a method used in conducting research to obtain information which is then processed according to the needs of specific purposes and uses.

Based on the description above, the researcher believes that the appropriate method used by researchers to carry out this research is descriptive method with a quantitative approach. The descriptive method is a method used to search for the elements, characteristics, and properties of a phenomenon [9]. This method starts with collecting, analyzing, and interpreting the data.

The population of the study was 189 students, and the sample was 66 students. The sampling technique refers to the opinion of Arikunto [10] which states that sampling can be done in various ways. One of which is by using purposive sampling technique.

The research data were collected through questionnaires and documentation. The data obtained were then analyzed by parametric statistics with simple linear regression testing and multiple regression or $\mathrm{t}$ test and $\mathrm{f}$ test. 


\section{RESULTS AND DISCUSSION}

\subsection{Test result}

After testing the data analysis requirements, namely the normality test and heteroscedasticity test, followed by hypothesis testing. After the data meets the requirements to be tested

\subsubsection{Testing Hypothesis 1 (H1)}

Table 1. Results of Testing Hypothesis 1 "t test" Coefficients

\begin{tabular}{|l|l|r|r|r|r|r|}
\hline \multicolumn{2}{|l|}{} & \multicolumn{2}{|c|}{$\begin{array}{c}\text { Unstandardized } \\
\text { Coefficients }\end{array}$} & $\begin{array}{c}\text { Standardized } \\
\text { Coefficients }\end{array}$ & & \\
\cline { 3 - 6 } Model & \multicolumn{1}{|c|}{ B } & Std. Error & Beta & \multicolumn{1}{c|}{ Sig. } \\
\hline 1 & (Constant) & 11.874 & 8.831 & & 1.345 & .184 \\
\cline { 2 - 7 } & Budaya organisasi & .904 & .110 & .716 & 8.208 & .000 \\
\hline
\end{tabular}

\section{. Dependent Variable: Student achievement}

The results of the linear regression test can be seen in the table above, for testing $\mathrm{X} 1$ against $\mathrm{Y}$ used partial hypothesis testing, based on the results of the tests carried out, for the organizational culture variable value of $8,208>\mathrm{t}$ table is 1.996 which means that for testing hypothesis $1 \mathrm{Ha}$ ) the alternative hypothesis is accepted. Therefore, organizational culture has a very positive and significant effect on student achievement. Moreover, it can be seen from the significance value of $0.000<0.05$ that means the alternative hypothesis $(\mathrm{Ha})$ for $\mathrm{H} 1$ is accepted.

Table 2. Correlational coefficients and coefficients are determined Hypothesis 1 (H1) Model Summary ${ }^{\mathrm{b}}$

\begin{tabular}{|l|r|r|r|r|}
\hline Model & $\mathrm{R}$ & R Square & $\begin{array}{r}\text { Adjusted } \\
\text { R Square }\end{array}$ & $\begin{array}{r}\text { Std. Error of } \\
\text { the Estim ate }\end{array}$ \\
\hline 1 & $.716^{\mathrm{a}}$ & .513 & .505 & 2.113 \\
\hline
\end{tabular}

a. Predictors: (Constant), Organizational Culture

b. Dependen Variable: Student achievement

The table above shows the variable $\mathrm{X} 1$ toward $\mathrm{Y}$ as the result of the correlation coefficient analysis. The value of 0.716 in column $\mathrm{R}$ means the correlation coefficient or the amount of organizational culture on student achievement of $71.6 \%$, and this is a very close relationship. In the $\mathrm{R}$ Square column the number is 0.513 which is the determinant coefficient or the magnitude of the influence of organizational culture variables on learning achievement of $51.3 \%$ which means that it has a strong enough influence.

\subsubsection{Hypothesis Testing 2}

The purpose of testing hypothesis 2 in this hypothesis is to examine the effect of teacher performance on learning achievement.
Table 3. Hypothesis 2 Testing Results "Coefficients t test

\begin{tabular}{|c|c|c|c|c|c|c|}
\hline \multirow[b]{2}{*}{ Model } & & \multicolumn{2}{|c|}{ Unstandardized Coefficients } & \multirow{2}{*}{\begin{tabular}{|c|}
$\begin{array}{c}\text { Standardized } \\
\text { Coefficients }\end{array}$ \\
Beta \\
\end{tabular}} & \multirow[b]{2}{*}{$t$} & \multirow[b]{2}{*}{ Sig. } \\
\hline & & $\mathrm{B}$ & Std. Error & & & \\
\hline \multirow[t]{2}{*}{1} & (Constant) & 9.746 & 8.844 & & 1.102 & .275 \\
\hline & Kineria guru & .929 & .110 & .726 & 8.437 & .000 \\
\hline
\end{tabular}

\section{a. Dependent Variable: Student achievement}

In the ' $t$ ' column in the table above, it is known that the largest value is 8.437 which is the $\mathrm{t}$ value for the teacher performance variable. From this result, it is interpreted at the $t$ table value of 1.994, which means that $t>t$ table or 8.437> 1.994. Based on this, it is concluded that the alternative hypothesis is accepted. The teacher performance has a positive and significant effect on the student achievement at SMPN 2 Cengal.

Table 4. Correlational Coefficient and Determinant Coefficient of Hypothesis $2(\mathrm{H} 2)$

Model Summary ${ }^{a}$

\begin{tabular}{|r|r|r|r|r|}
\hline Model & R & R Square & \multicolumn{1}{c|}{$\begin{array}{c}\text { Adjusted R } \\
\text { Square }\end{array}$} & $\begin{array}{c}\text { Std. } \\
\text { Error of the } \\
\text { Estimate }\end{array}$ \\
\hline 1 & $.726^{\mathrm{a}}$ & .527 & .519 & 2.083 \\
\hline
\end{tabular}

a. Predictors: (Constant), Teacher performance

b. Dependent Variable: Student Achievement

Based on the table above, it can be seen in column $\mathrm{R}$ that there is a value of 0.726 which is the amount of the correlation coefficient of the relationship between teacher performance and student learning achievement. The percentage was $72.6 \%$. This relationship falls into the very close category. The value of 0.527 contained in the $\mathrm{R}$ Square column, which is the determinant coefficient or the amount of influence of teacher performance variables thatb has an effect $52.7 \%$ on student achievement of SMPN 2 Cengal. This influence is quite high.

\subsubsection{Hypothesis Testing 3}

The purpose of testing hypothesis 3 is that the variables are independently tested against the related variables. The results obtained from the above tests can be seen in the table below.

Table 5. Results of Hypothesis Testing 3 "F Test" Anova $^{a}$

\begin{tabular}{lrrrrr}
\hline \multicolumn{1}{c}{ Model } & $\begin{array}{c}\text { Sum of } \\
\text { Squares }\end{array}$ & \multicolumn{1}{c}{ Df } & $\begin{array}{c}\text { Mean } \\
\text { Square }\end{array}$ & F & Sig. \\
\hline Regression & 309.662 & 2 & 154.831 & 35.230 & $000^{b}$ \\
\hline Residual & 276.875 & 63 & 4.395 & & \\
\hline Total & 586.536 & 65 & & & \\
\hline
\end{tabular}

a. Dependent Variable: Student achievement

b. Predictors: (Constant), teacher performance, Organizational culture 
By using $\mathrm{f}$ test which is carried out simultaneously as in the table above, it can be seen in column $\mathrm{F}$ there is a value of $35.320>\mathrm{F}$ Table of 3.14. It means that there is positive and significant effect of organizational culture and teacher performance on student achievement in SMPN 2 Cengal.

Of these two independent variables have an influence on the dependent variable which can be seen from the following table.

Table 6. Correlational Coefficient and Determinant Coefficient of Hypothesis 3 (H3) Model Summary b.

\begin{tabular}{|l|l|r|r|r|}
\hline Model & R & R Square & $\begin{array}{c}\text { Adjusted } \\
\text { R Square }\end{array}$ & $\begin{array}{r}\text { Std. Error } \\
\text { of the Estimate }\end{array}$ \\
\hline 1 &, $727^{\mathrm{a}}$ & .528 & .513 & 2.096 \\
\hline
\end{tabular}

a. Predictors: (Constant), teacher performance, Organizational culture

b. Dependent Variable: student achievement

The table above is the result of multiple test analysis. In Column $\mathrm{R}$ there is a value of 0.727 or $72.2 \%$ of the variable organizational culture and teacher performance on student achievement, so this is a very close relationship. It can be seen in the column R Square 0.528 which means that organizational culture and teacher performance have an effect of $52.8 \%$ on student achievement at SMPN 2 Cengal. The influence can be categorized into a fairly high category.

\subsection{Discussion}

Each variable in this study shows the results that the independent variable has a close relationship and a positive influence on the dependent variable. Organizational culture and teacher performance have a positive and significant impact on student learning presences at SMPN 2 Cengal.

\subsubsection{Organizational Culture againts Student Achievement}

Based on the partial test results, it is clear that the relationship value between the organizational culture and the student achievement is $71.6 \%$. This includes a very close relationship. The value of the influence in the organizational culture variable on learning achievement is $51.3 \%$ which means it has a strong enough influence. From the results of the figures above, it provides an overview of the culture and habits that are carried out continuously have an impact on students to get maximum learning achievement. Thus the culture that has been formed is an academic culture that is compatible with the noble values of national education. The essence of education is carried out with the aim that humans have good and praiseworthy morals.

\subsubsection{Teacher Performance against Student Achievement}

For the correlation coefficient of the relationship between teacher performance and student learning achievement can be percentage of $72.6 \%$. This relationship falls into the very close category. As for the value of the influence of the teacher performance variable has an effect of $52.7 \%$ on student achievement of SMPN 2 Cengal. This influence is quite high. This is of course a note and input for teachers to optimize learning which is very important for every teacher because from the research results it is clear that teacher performance has a big impact in supporting students to have good learning achievement.

\subsubsection{The Influence of Organizational Culture and Teacher Performance on Student Learning Achievement}

When the simultaneous test is carried, the results are that organizational culture and teacher performance have a relationship of $72.2 \%$ in the organizational culture variable and teacher performance on student learning achievement. The result indicates a very close relationship with the independent variable. Meanwhile, organizational culture and teacher performance had an effect of $52.8 \%$ on student achievement at SMPN 2 Cengal. The influence can be categorized into a fairly high category. It should be remembered that all the elements that exist have an impact on students to reach the learning achievement.

The results of the research that have been carried out support several previous studies such as a research conducted by Khairani (2013). She notes that organizational culture enable to influence student achievement. Likewise, teacher performance affects learning achievement. With this research it can be emphasized that it is not only learning achievement that affects the two variables studied as independent variables. This research provides substance that this research has implications for learning achievement.

Juwita (2016), Masruri, Abdullah and Egar (2017), and Zakaria (2014) conducted a study of organizational culture on teacher performance. In several previous studies were examined the variables that are currently being studied as independent variables. It's just that the substance of the research certainly has implications for learning outcomes [11].

The same thing was noted by Eriska, Rustiyarso and Purwaningsih [12]. They emphasize that organizational culture and teacher performance have a great impact on student achievement, especially in student-focused subjects. Likewise, Alhusain, Kristiawan, and Eddy [13] studied work discipline on teacher performance. It was examined that the variables 
currently used as independent variables that have a major impact on student achievement.

As a scientific study, researchers have ordered the results of the study by referring the research procedures. In terms of writing, it has been analyzed in accordance with the provisions of the scientific principles of a work, but the researcher realizes that there are still many shortcomings and weaknesses in this study because there are several factors that influence it. These factors include limited time in conducting research, limited costs in conducting research, and limited ability of researchers in conducting research. Researchers expect the results of this study to become a reference for conducting further similar research.

\section{CONCLUSION}

The results of study are stated in the following: 1) There is a positive and significant influence of organizational culture on students' achievement of SMPN 2 Cengal. 2) There is a positive and significant effect of teacher performance on the learning achievement of students at SMPN 2 Cengal. 3) There is an effect of organizational culture and teacher performance with a positive and significant effect on student achievement of SMPN 2 Cengal.

\section{REFERENCES}

[1] Pemerintah Republik Indonesia Undang-Undang No 20 tahun 2003 Pasal 1 Pasal 2.

[2] Kementerian Pendidikan Nasional. Undangundang Nomor 20 Tahun 2003 tentang Sistem Pendidikan Nasional. Jakarta: Kementerian Pendidikan Nasional.

[3] Sudjana, N. Penilaian hasil proses belajar mengajar. Bandung: Remaja Rosdakarya, 2009.

[4] Sugihartono. Psikologi pendidikan. Yogyakarta: UNY Press. 2007.

[5] Robbins, S. P., \& Timothy, J. A. Perilaku Organisasi (terjemahan). Jakarta: Salemba Empat, 2008.

[6] Rubiyanto, A. Pengertian kinerja guru dalam pembelajaran, 2010.

[7] Khairani. Pengaruh budaya organisasi dan kinerja guru terhadap prestasi belajar siswa Sekolah Menengah Atas Negeri 1 Krueng Barona Jaya. Banda Aceh: Universitas Syiah Kuala, 2013.

[8] Sugiyono. Metode Penelitian Kualitatif, Kuantitatif dan R\&D. Bandung: Alfabeta, 2017.

[9] Suryana. Metodologi Penelitian. Bandung: Universitas Pendidikan Indonesia, 2010.
[10] Masruri, I. K., Abdullah, G., \& Egar, N. Pengaruh budaya organisasi sekolah dan motivasi kerja guru terhadap kinerja guru sekolah dasar di Kecamatan Petarukan Kabupaten Pemalang. Jurnal Manajemen Pendidikan, 2017.

[11] Juwita, M. Pengaruh budaya organisasi, komitmen guru dan motivasi kerja terhadap kinerja guru SMP Negeri 03 Mukomuko. Jakarta: Universitas Terbuka, 2016.

[12] Elisa, H Rustuyars, \& Purwaningsih E. (2015). pengaruh budaya organisasi terhadap hasil belajar mata pelajaran peminatan siswa. Jurnal pendidikan dan pembelajaran khatulistiwa, Volume 4 Nomor 12

[13] Alhuzain, Kristiawan \& Eddy (2020) Pengaruh Motivasi Kerja dan Disiplin Kerja Terhadap Kinerja Guru Di SMA OKU. Jurnal Pendidikan Vol 4 No 3 tahun 2020 